\title{
Biogeochemical markers of organic matter along the Wight-Cherbourg transect (central English Channel)
}

\author{
M. Monaïm ISMAÏLI ${ }^{a}$, Léon SERVE $^{b^{*}}$, François GADEL $^{\dagger c}$, Robert LAFITE $^{\text {d }}$, Hervé TEXIER ${ }^{a}$ \\ ${ }^{a}$ Upres-A 6143, Morphodynamique continentale et côtière, université de Caen, 14032 Caen, France \\ ${ }^{\mathrm{b}}$ Laboratoire de biologie physico-chimique, université de Perpignan, 52, avenue de Villeneuve, 66860 Perpignan cedex, \\ France. serve@univ-perp.fr \\ ${ }^{c}$ Cefrem, université de Perpignan, 66860 Perpignan, France \\ ${ }^{d}$ Upres-A 6143, Morphodynamique continentale et côtière, université de Rouen, 76821 Mont-Saint-Aignan cedex, \\ France \\ ${ }^{\dagger}$ In memory of François Gadel, our colleague and friend who passed away suddenly on April 25, 1999. He contributed \\ greatly to all our work on organic matter.
}

(Received 18 September 1998, revised 3 February 1999, accepted 10 February 1999)

\begin{abstract}
Three cruises on the Wight-Cherbourg transect were undertaken during the FluxManche II Programme in order to study the origin, nature and behaviour of organic matter inputs to the waters of the English Channel. Suspended particulate material (SPM) collected from surface and deep waters at each station was analysed at elemental level for Particulate Organic Carbon and Particulate Organic Nitrogen (POC, PON), at molecular level for main classes of organic compounds using Pyrolysis-Gas Chromatography coupled with Mass Spectrometry (Py-GC-MS) and for phenolic compounds, particularly ligninderived phenols, using High Performance Liquid Chromatography (HPLC). The SPM content increases from the French (south) to the English coast (north) with the lowest values being observed in the central waters of the Channel. This distribution is essentially linked to resuspension processes and the influence of terrigenous inputs from the Solent river inside English coastal waters. Py-GC-MS analyses show that organic material within French waters is usually marine in character and is more degraded than in English waters. Organic material in the central waters always shows the highest state of degradation, probably due to its long transit time in the "central water mass" from the Atlantic to the English Channel. Autochthonous and allochthonous organic tracers were positively identified through the use of HPLC analyses. Seasonal variations in the system lead to qualitative changes in terrigenous inputs (lignin-derived phenols). To our knowledge, it is the first time that phenolic compounds of autochthonous origin have been recorded in central Channel waters. Indeed, it is the study of the distribution and composition of hydroxybenzyl phenols which has allowed an estimate of the marine contribution to the particulate organic matter to be made. These compounds may originate from phytoplankton and macroalgae tissues developing in the coastal environments of the Channel. @ Elsevier, Paris / Ifremer / CNRS / IRD
\end{abstract}

suspended particulate matter / organic compounds / phenolic markers / biogeochemistry / English Channel

Résumé - Marqueurs biogéochimiques de la matière organique sur la radiale Wight-Cherbourg (Manche centrale). L'origine, la nature et le comportement des apports de matière organique dans les eaux de la Manche ont été étudiés au cours de trois campagnes effectuées sur la radiale Wight-Cherbourg, dans le cadre du programme FluxManche II. Le matériel particulaire en suspension (MPS) prélevé en surface et au fond des eaux de chaque station a été étudié au niveau élémentaire : carbone organique particulaire (COP), azote organique particulaire (AOP) et moléculaire : classes principales de composés organiques par pyrolyse - chromatographie gazeuse couplée à la spectrométrie de masse (Py-CG-SM) et composés phénoliques, particulièrement les phénols dérivés de la lignine par chromatographie liquide à haute perfor-

* Correspondence and reprints 
mance (CLHP). Un gradient croissant de matière particulaire en suspension (MPS) s'établit du sud vers le nord, avec les plus faibles teneurs dans les eaux centrales. Cette répartition est liée essentiellement à l'importance des remises en suspension dans les eaux anglaises et à l'influence des apports telluriques issus du Solent. L'analyse par Py-CG-SM montre que le matériel organique dans les eaux françaises a souvent un caractère marin et plus dégradé que dans les eaux anglaises. Les eaux centrales se caractérisent toujours par l'état le plus dégradé de la matière organique, probablement en raison du long transit dans la " veine d'eau centrale » atlantique alimentant la Manche. La technique CLHP a permis d'identifier des traceurs organiques autochtones et allochtones. Les variations saisonnières se traduisent par un changement qualitatif de l'apport terrestre (phénols ligneux). À notre connaissance, c'est la première fois que des composés phénoliques d'urigine autochtone sont mis en évidence dans les eaux de la Manche centrale. En effet, les phénols hydroxybenzyles, par leur répartition et leur composition, ont permis d'estimer une contribution marine au matériel organique particulaire. Ils auraient pour origine le phytoplancton et les thalles de macroalgues se développant sur les côtes de la Manche. (Elsevier, Paris / Ifremer / CNRS / IRD

\section{matière particulaire en suspension / composés organiques / marqueurs phénoliques / biogéochimie / Manche}

\section{INTRODUCTION}

The suspended organic matter in coastal waters has a double origin: indigenous production and continental riverine contribution $[11,20,31,33]$. In coastal environments, a significant proportion of the terrestrial organic material is transported in the form of woody components
$[20,29,32]$. The major point of interest of these woody components is their refractory character.

The Pyrolysis-Gas Chromatography-Mass Spectrometry (Py-GC-MS) technique allows the major classes of organic compounds to be identified. It was used to characterize the chemical nature of polymeric organic material $[10,11,38,41]$. This analysis technique is a powerful

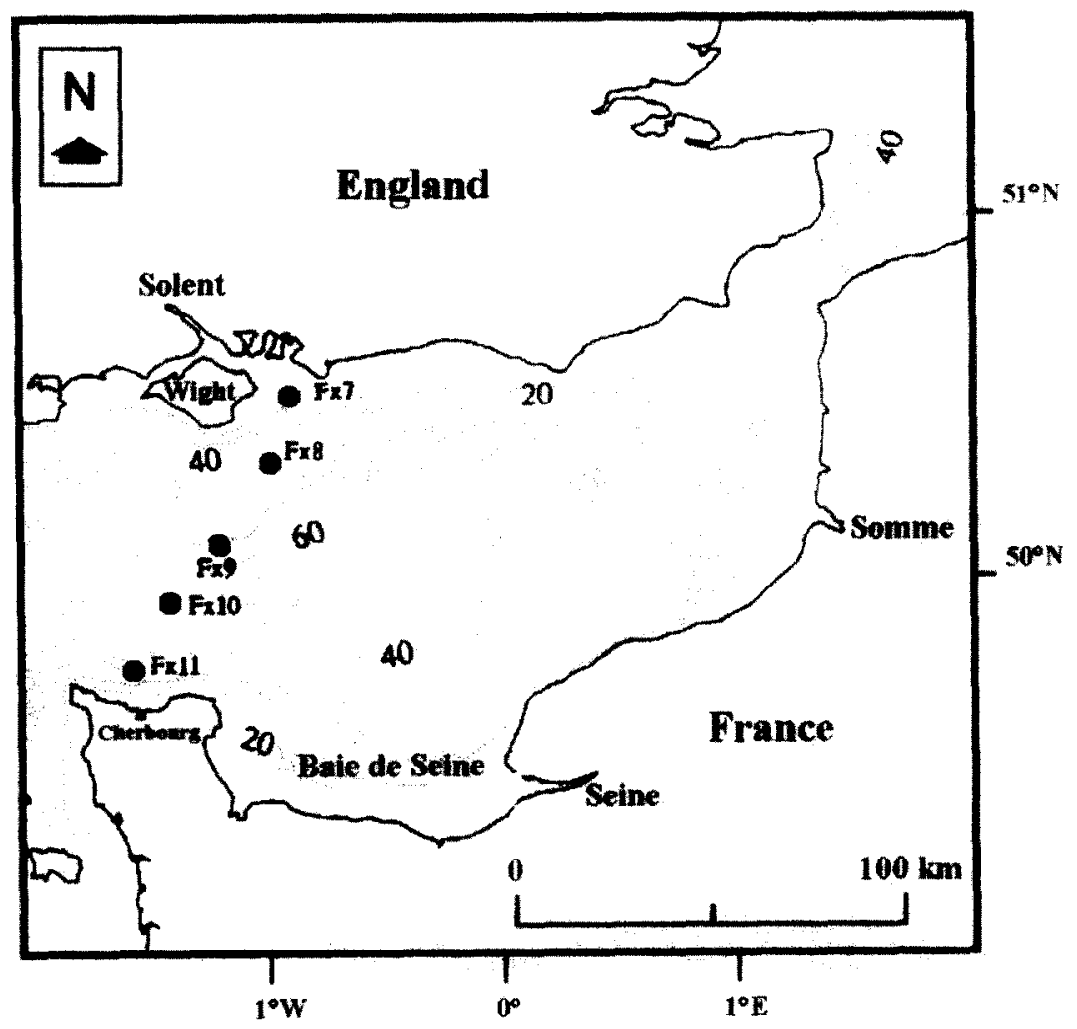

Figure 1. Bathymetry and situation of FluxManche II sampling stations along the Wight-Cherbourg transect. 
Table I. Distribution of the organic compounds (in relative percents of total particulate organic matter) in suspended material analysed by Py-GC-MS in the bottom waters at FX7, FX9 and FX11 stations, during November 1994, March and July 1995 transects.

\begin{tabular}{|c|c|c|c|c|c|c|c|c|c|c|}
\hline \multirow{2}{*}{\multicolumn{2}{|c|}{$\begin{array}{l}\text { Classes individual } \\
\text { compounds }\end{array}$}} & \multicolumn{3}{|c|}{ Nov. 94} & \multicolumn{3}{|c|}{ Mar. 95} & \multicolumn{3}{|c|}{ Jul. 95} \\
\hline & & \multirow{2}{*}{$\frac{\text { FX7b }}{18.3}$} & \multirow{2}{*}{$\frac{\text { FX9b }}{22.8}$} & \multirow{2}{*}{$\frac{\text { FX11b }}{20.7}$} & \multirow{2}{*}{$\frac{\mathbf{F X 7 b}}{17.1}$} & \multirow{2}{*}{$\frac{\text { FX9b }}{20.4}$} & \multirow{2}{*}{$\frac{\text { FX11b }}{19.8}$} & \multirow{2}{*}{$\frac{\mathbf{F X} 7 \mathbf{b}}{18.8}$} & \multirow{2}{*}{$\frac{\text { FX9b }}{22}$} & \multirow{2}{*}{$\frac{\text { FX11b }}{21.5}$} \\
\hline A.H. & Benzene & & & & & & & & & \\
\hline N.C. & Acetonitrile & 0.4 & 0.5 & 0.6 & 0.8 & 1.1 & 0.5 & 1 & 0.5 & 0.5 \\
\hline A.H. & Toluene & 2 & 2 & 2.2 & 2.2 & 2 & 2 & 1.9 & 1.9 & 2 \\
\hline N.C. & Valeronitrile & 4.5 & 5 & 5.6 & 6.3 & 5.5 & 4.9 & 5 & 4.5 & 5.1 \\
\hline N.C. & Pyridine & 1 & 1 & 2 & 6.4 & 0.8 & 0.5 & 5 & 3.7 & 1.7 \\
\hline A.H. & Styrene & 11.5 & 14.4 & 12.6 & 7.9 & 17.4 & 16.8 & 19.1 & 22.6 & 17.1 \\
\hline Sug. & Cyclopentenone & 0.7 & 0.9 & 2.3 & 1 & 0.8 & 2.6 & 1.9 & 1.5 & 1.3 \\
\hline Sug. & 3-Furanaldehyde & 2.1 & 1 & 1 & 1.7 & 2.5 & 2.5 & 1.3 & 0.8 & 1.6 \\
\hline Sug. & Furfural & 16.7 & 2.1 & 2 & 5.9 & 4.5 & 4 & 2.5 & 1.8 & 2.2 \\
\hline Sug. & Acetic acid & 2.2 & 1.8 & 1.7 & 3.4 & 2.2 & 2.4 & 1.6 & 1.9 & 1.7 \\
\hline N.C. & Pyrrol & 4.1 & 6.9 & 9.7 & 10.1 & 9.8 & 8.7 & 8.5 & 7.1 & 9.6 \\
\hline N.C. & 3-Methylpyrrol & 0.4 & 2.7 & 3 & 2.9 & 2.3 & 2.6 & 2.4 & 2.6 & 3 \\
\hline N.C. & 2-Methylpyrrol & 1.1 & 3.1 & 2.7 & 4.2 & 2.3 & 3 & 2.4 & 2.7 & 3.1 \\
\hline Sug. & 5-Methyl-2-Furfural & 0.8 & 0.4 & 0.5 & 0.7 & 0.6 & 0.7 & 0.5 & 0.4 & 0.4 \\
\hline A.S. & Acetamide & 0.3 & 0.7 & 0.9 & 0.9 & 0.8 & 0.8 & 2.2 & 0.7 & 0.8 \\
\hline N.C. & Benzylonitrile & 1.3 & 2 & 2.8 & 2.8 & 1.9 & 2.1 & 2.2 & 1.8 & 1.9 \\
\hline Phe. & Phenol & 9.3 & 13.2 & 11.2 & 9.5 & 9.4 & 8.8 & 8.5 & 8.2 & 8.7 \\
\hline Phe. & Phenyletanol & 1.3 & 0.9 & 0.5 & 0.3 & 0.5 & 0.4 & 0.2 & 0.2 & 0.4 \\
\hline Phe. & m cresol & 3.6 & 8.2 & 8.4 & 4.4 & 5 & 6.4 & 4.9 & 6.7 & 7.8 \\
\hline Phe. & p cresol & 1.4 & 1 & 0.9 & 1.5 & 1.7 & 1.4 & 0.8 & 0.7 & 1 \\
\hline Phe. & Methylphenol & 2.1 & 1.3 & 1.4 & 0.7 & 1.2 & 1 & 0.8 & 0.7 & 1.2 \\
\hline N.C. & 2,3-dihydrobenzofurane & 2.3 & 2.3 & 2.9 & 2.9 & 3 & 1.8 & 2.6 & 1.9 & 2.6 \\
\hline N.C. & Indol & 12.6 & 5.6 & 4.5 & 6.5 & 4.3 & 6.2 & 5.9 & 5.1 & 4.8 \\
\hline $\mathrm{R} 1$ & Benzene/Toluene & 9.15 & 11.40 & 9.41 & 7.77 & 10.20 & 9.90 & 9.89 & 11.58 & 10.75 \\
\hline $\mathrm{R} 2$ & (Furf.+Acetic ac.)/Pyrrol & 4.61 & 0.57 & 0.38 & 0.92 & 0.68 & 0.74 & 0.48 & 0.52 & 0.41 \\
\hline R3 & Acetonitrile/Pyrrol & 0.10 & 0.07 & 0.06 & 0.08 & 0.11 & 0.06 & 0.12 & 0.07 & 0.05 \\
\hline A.H. & Aromatic hydrocarbons & 31.8 & 39.2 & 35.5 & 27.2 & 39.8 & 38.6 & 39.8 & 46.5 & 40.6 \\
\hline N.C. & Nitrogenous compounds & 27.7 & 29.1 & 33.8 & 42.9 & 31 & 30.3 & 35 & 29.9 & 32.3 \\
\hline Sug. & Sugars & 22.5 & 6.2 & 7.5 & 12.7 & 10.6 & 12.2 & 7.8 & 6.4 & 7.2 \\
\hline Phe. & Phenols & 17.7 & 24.6 & 22.4 & 16.4 & 17.8 & 18 & 15.2 & 16.5 & 19.1 \\
\hline A.S. & Amino sugars & 0.3 & 0.7 & 0.9 & 0.9 & 0.8 & 0.8 & 2.2 & 0.7 & 0.8 \\
\hline
\end{tabular}

tool for defining, both quantitatively and qualitatively, the principal units which constitute complex biopolymer and condensed products.

Phenolic compounds are generally used as tracers of terrestrial organic contributions in the marine environment $[14,15,20,21,26,31]$. Alkaline oxidation with cupric oxide $(\mathrm{CuO})$ was used to release the monomeric hydroxyaromatic components of lignin, in order to characterize and quantify the organic matter of terrestrial origin in various environments $[20,27,28,37]$.

River inputs to the Channel and the characterization and behaviour of terrestrial organic matter in the waters of the Channel have scarcely been studied $[1,8,30,32,39]$.

The FluxManche II Programme and more particularly the "Fluxes and Biogeochemical Processes" task aimed to study particulate and dissolved material transfer in the English Channel and to understand modifications in water flow and transported elements during their passage through the English Channel towards the North Sea.

Within the framework of this programme, our aim was to study the biogeochemical behaviour of organic inputs to the hydrodynamic system of the English Channel. Elemental analyses for Suspended Particulate Material, Particulate Organic Carbon and Particulate Organic Nitrogen (SPM, POC, PON) were carried out along with determination of the major classes of organic compounds using Pyrolysis-Gaz Chromatography coupled with Mass Spectrometry (Py-GC-MS) and analysis of terrestrial input biogeomarkers (lignin-derived phenols) contained in particulate material produced exclusively by tracheophytes, 
M.M. ISMAÏLl et al.

Table II. Nomenclature and chemical strucure of cupric oxide oxidation lignin monomers analysed by high performance liquid chromatography (HPLC).

\begin{tabular}{|c|c|c|c|c|c|}
\hline \multirow[t]{2}{*}{ Series } & \multicolumn{2}{|c|}{ Suhstituants } & \multicolumn{3}{|c|}{ Common name } \\
\hline & & & Acid & Aldehyde & Keton \\
\hline \multicolumn{6}{|l|}{ C6-C1: Benzyl } \\
\hline 4-Hydroxybenzyl $(\mathrm{H})$ & $\mathbf{H}$ & $\mathrm{H}$ & p-Hydroxybenzoic & $p$-Hydroxybenzaldehyde & \\
\hline 3-Methoxy-4-hydroxybenzyl (V) & $\mathrm{H}$ & $\mathrm{OCH} 3$ & Vanillic & Vanillin & \\
\hline 3,5-Dimethoxy-4-hydroxybenzyl (S) & $\mathrm{OCH} 3$ & $\mathrm{OCH} 3$ & Syringic & Syringaldehyde & \\
\hline \multicolumn{6}{|l|}{ C6-C2 : Phenyl ethyl } \\
\hline 4-Hydroxyphenyl ethyl $(\mathrm{H})$ & $\mathrm{H}$ & $\mathrm{H}$ & & & $p$-Hydroxyacetophenon \\
\hline 3-Méthoxy-4-hydroxyphényl éthyl (V) & $\mathbf{H}$ & $\mathrm{OCH} 3$ & & & Acetovanillon \\
\hline 3,5-Dimethoxy-4-hydroxyphenyl ethyl (S) & $\mathrm{OCH} 3$ & $\mathrm{OCH} 3$ & & & Acetosyringon \\
\hline \multicolumn{6}{|l|}{ C6-C3 : Phenyl propene } \\
\hline 4-Hydroxyphenyl propyl (C) & $\mathrm{H}$ & $\mathrm{H}$ & $p$-Coumaric & & \\
\hline 3-Methoxy-4-Hydroxyphenyl propyl (C) & $\mathbf{H}$ & $\mathrm{OCH} 3$ & Ferulic & & \\
\hline
\end{tabular}

using cupric oxide alkaline oxidation and High Performance Liquid Chromatography (HPLC) techniques. Sampling and analytical strategy (seasonal sampling along the Wight-Cherbourg transect, at surface and bottom levels) enabled information on the seasonal variations in organic contributions to be obtained and the nature of continental inputs as compared to marine inputs to be characterized in molecular terms.

\section{MATERIAL AND METHODS}

Water sampling was done using Niskin bottles during three campaigns (November 1994, March and July 1995) on the Wight-Cherbourg transect (figure 1). At each station, two samples of about $20 \mathrm{~L}$ each were taken at the surface and bottom levels of the water column (table III). Each 20-L sample (resulting from mixing together the contents of four 5-L Niskin bottles) was equally divided into four sub-samples by filtration on board through Whatman $\mathrm{GF} / \mathrm{F}$ filters which were preheated at $450^{\circ} \mathrm{C}$ for $4 \mathrm{~h}$ and then preweighed. After filtration, the filters were rinsed with ultrapure water to eliminate salts and dried to $50{ }^{\circ} \mathrm{C}$ during $12 \mathrm{~h}$. They were then stored in a desiccator and were weighed to evaluate the suspended particulate matter (SPM).

The POC concentrations were measured by dry combustion of the filters in a Leco CS 125 carbon analyser. After decarbonation with $2 \mathrm{~N} \mathrm{HCl}$, the dried filters were oxydised in an induction furnace and the liberated $\mathrm{CO}_{2}$ was measured quantitatively by infrared absorption (precision: $2 \%$ of the average value). The PON contents were determined by the Kjeldahl method, using a Technicon continuous flow spectrocolorimeter (precision: $0.3 \%$ of the average value).

Analysis of the major classes of organic compounds was carried out by coupling Py-GC-MS. A CDS 1000 pyrolysis probe is directly coupled to a Perkin-Elmer 8700 gas chromatograph equipped with a TR-WAX capillary column (length: $30 \mathrm{~m}$, diameter: $0.32 \mathrm{~mm}$, phase thickness: $0.50 \mathrm{~m}$ ). Pyrolysis temperature was $700^{\circ} \mathrm{C}$ for $10 \mathrm{~s}$ and the column temperature was programmed up to $240^{\circ} \mathrm{C}$ at a rate of $6^{\circ} \mathrm{C} \mathrm{min}-1$. Pyrolysis fragments were identified by coupling to an HP 5989 mass spectrometer. Twentythree major peaks were selected on the pyrochromatograms and each selected compound was expressed as a percentage of the sum of the surface of these 23 peaks (table I). Pyrolysis products were grouped into five main families, each of them including similar molecules or closely chemical structures: aromatic hydrocarbons, nitrogenous compounds, sugars, phenols and amino sugars.

Phenolic compounds were determined by high performance liquid chromatography (HPLC) after cupric oxide alkaline oxidation and extraction with ethyl acetate $[7,13,17]$. The limit of detection was $10^{-4} \mathrm{~g}$ and the precision of the method was about $2 \%$ for each compound. Separation and quantification of phenolic monomers was carried out by HPLC [7, 37]. On a total of 28 identified products, eleven represented the monomers constituting lignin and were taken into account according to Hedges and Ertel [17]. The products of oxydative hydrolysis of lignin belong to the following three series: 4-hydroxybenzyl "H" (p-hydroxybenzoic acid, p-hydroxybenzaldehyde, p-hydroxyacetophenone), 3-methoxy-4-hydroxybenzylic 

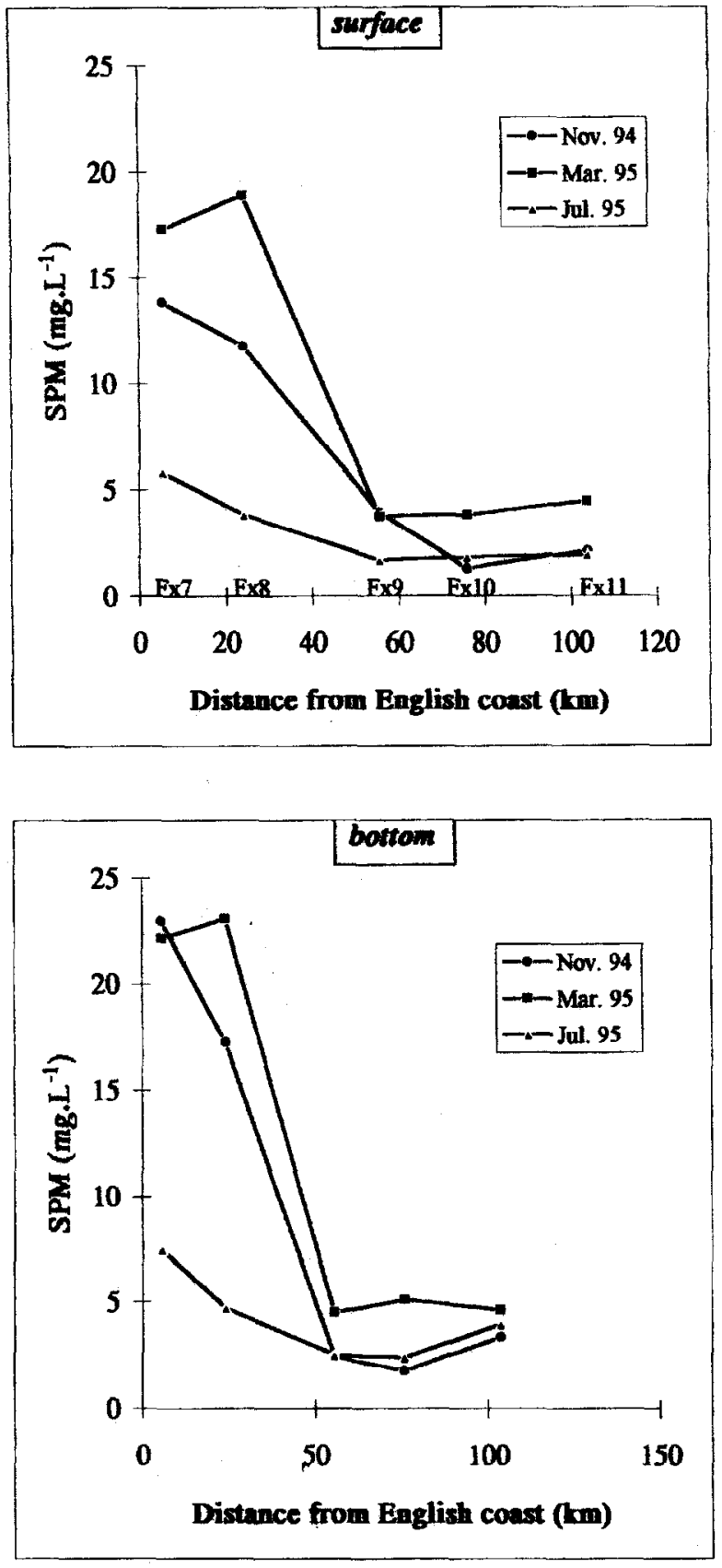

Figure 2. Distribution of suspended particulate matter (SPM) in surface and bottom waters, along the Wight-Cherbourg transect, in November 1994, March and July 1995.

"V" (Vanillyl) and 3.5-methoxy-4-hydroxybenzylic "S" (Syringyl). Each one of these three series presents a side chain alkyl with 1, 2 or 3 carbon atoms. The compounds in $\mathrm{C} 6-\mathrm{C} 1$ may be acids or aldehydes, those in $\mathrm{C} 6-\mathrm{C} 2$ are ketones and those in $\mathrm{C} 6-\mathrm{C} 3$ are acids. The latter, having a phenylpropenic structure, belong to the Cinnamyl " $\mathrm{C}$ " serie (ferulic acid, p-coumaric acid): they are summarized in table II [37].

Phenol separation was carried out on a Merck analytical column ( $250 \mathrm{~mm}$ long $\times 4 \mathrm{~mm}$ in diameter). The stationary phase consists of Lichrosorb, reversed phase $\mathrm{C} 18$ of $5 \mu \mathrm{m}$ granulometry, equipped with a precolumn $(40 \mathrm{~mm}$ long) containing the same phase. Elution was done using a ternary eluent (water, acetonitrile, acetic acid), according to a high pressure binary gradient defined by Charrière [7]. Identification of the eluted products was done by comparison of their retention times with those of commercial products, detection being done in UV at $275 \mathrm{~nm}$, even after a co-injection if necessary. The internal standards of phloroglucinol (1,3,5-benzenetriol) and p-anisic acid (p-methoxybenzoic acid) allow the identified products to be determined quantitatively.

\section{RESULTS}

\subsection{Suspended particulate matter (SPM)}

Along the transect (figure 1), the SPM concentrations for the periods concerned vary from 1.3 to $18.9 \mathrm{mg} \mathrm{L}^{-1}$ on the surface and 1.8 to $23.1 \mathrm{mg} \mathrm{L}^{-1}$ at the bottom (figure 2). English coastal waters (FX7 and FX8) present average SPM values which are four to five times higher than in the central or French waters of the transect. Generally, the SPM concentrations are higher in the bottom layer than on the surface and the most notable fluctuations are observed in English waters. In fact, in these waters, SPM contents can vary by a factor of 10 on a semi-diurnal cycle scale [25].

\subsection{Particulate organic matter: POC, PON}

For all the samples, the rates of POC in \% of SPM are higher on the French side than on the English side (figure 3 ). They vary from 1.5 to $3.8 \%$ and 1.5 to $8.2 \%$, respectively on the surface and in the bottom layers in November; 2.4 to $5.1 \%$ with similar values between the bottom and surface in March; 5.4 to $9.8 \%$ and 4.3 to $9.5 \%$ respectively on the surface and at the bottom in July.

The PON values generally present the same evolution as the POC. Concentrations vary from 0.13 to $0.43 \%$ and 0.13 to $0.86 \%$ respectively on the surface and at the bottom in November; from 0.28 to $0.64 \%$ with roughly similar values between the surface and bottom in March; 


\section{Nov, 94}
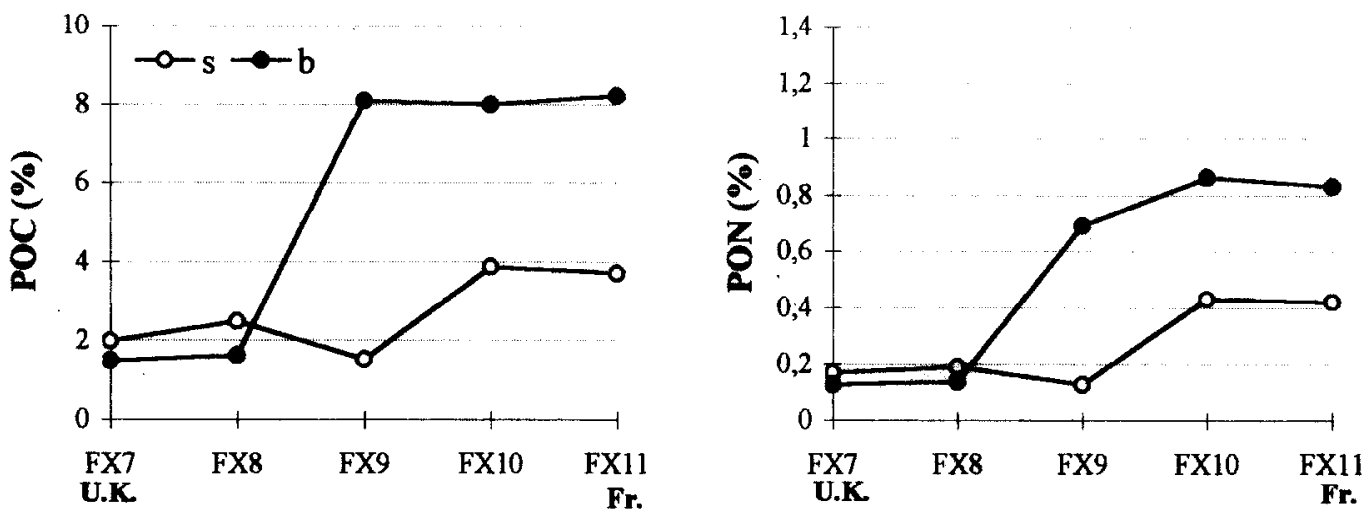

\section{$\underline{\text { Mar. } 95}$}
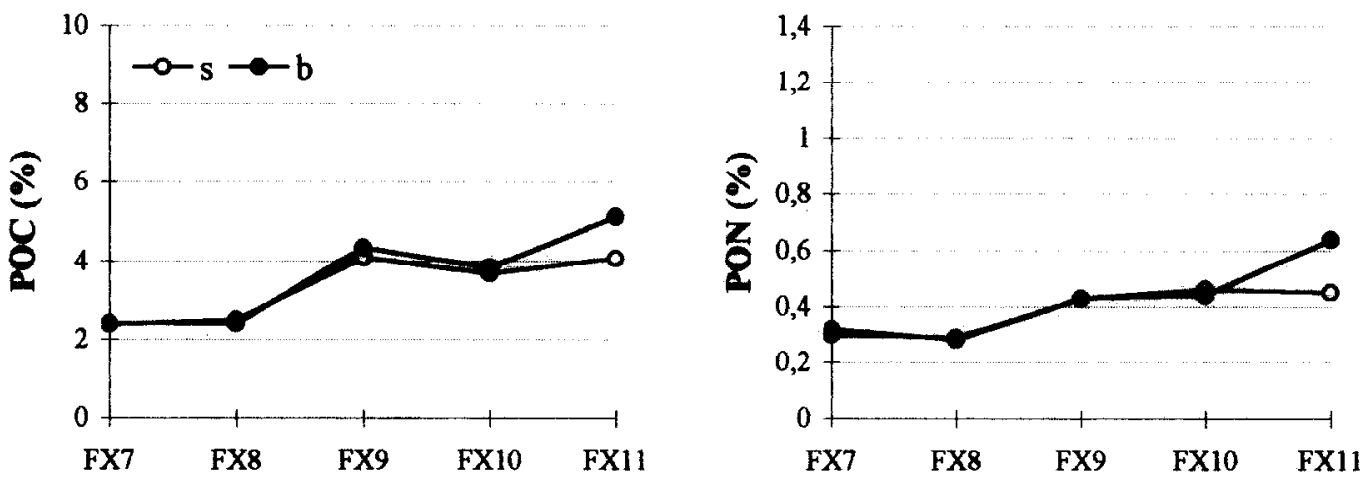

\section{$\underline{\text { Jul. } 95}$}
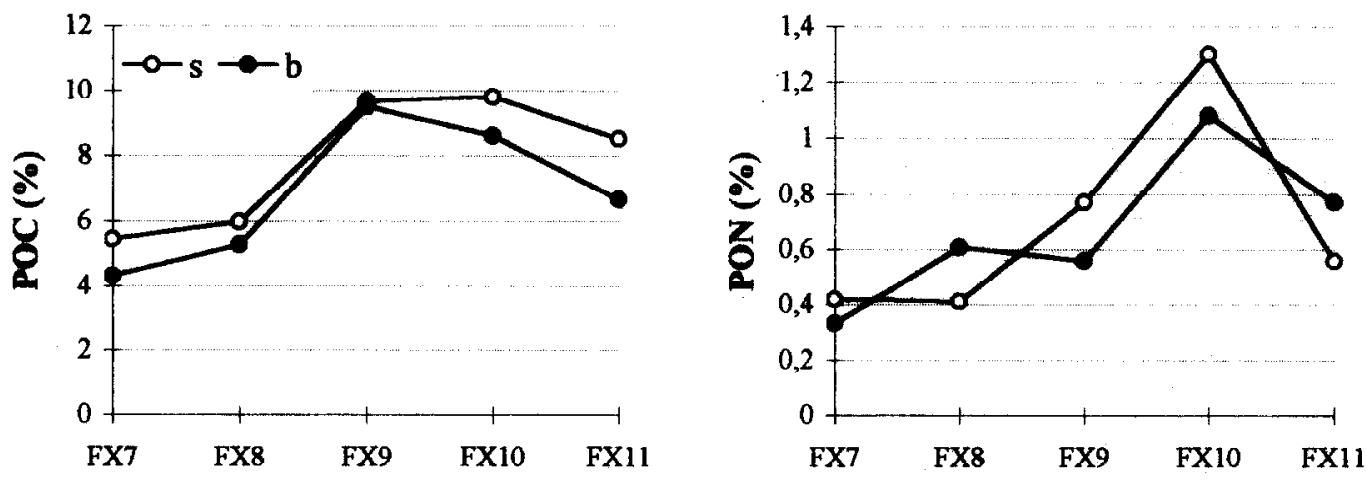

Figure 3. Distribution of particulate organic carbon (POC) and Kjeldahl nitrogen (PON) contents in the particulate matter of surface (s) and bottom (b) waters of the Wight-Cherbourg transect. 
Table III. Elemental analysis for particulate organic carbon (POC\%), PON\%, C/N ratios and results of phenolic compounds analyses by HPLC: Hydroxybenzyl (H), Vanillyl (V), Syringyl (S) and Cinnamyl (C) compounds. $\Sigma 11$ represents the sum of S $+\mathrm{V}+\mathrm{C}+\mathrm{H}$ and $\lambda 8$ the sum of $\mathrm{S}+\mathrm{V}+\mathrm{C}$ compounds. $\mathrm{H} / \mathrm{V}, \mathrm{C} / \mathrm{V}$ and $\mathrm{H} / \mathrm{V}$ ratios can lead to an indication of taxonomic origin of the particulate organic matter.

\begin{tabular}{|c|c|c|c|c|c|c|c|c|c|c|}
\hline & Fx7s & Fx8s & Fx9s & Fx10s & Fx11s & Fx7b & Fx8b & Fx9b & Fx10b & Fx11b \\
\hline \multicolumn{11}{|c|}{ November 94} \\
\hline Depth (m) & 3.4 & 0.7 & 0.6 & 1.8 & 3.8 & 16.6 & 25.3 & 92.4 & 71.3 & 52.2 \\
\hline $\mathrm{POC}(\%)$ & 1.98 & 2.49 & 1.53 & 3.86 & 3.70 & 1.49 & 1.62 & 8.08 & 7.99 & 8.21 \\
\hline PON $(\%)$ & 0.17 & 0.19 & 0.13 & 0.43 & 0.42 & 0.13 & 0.14 & 0.69 & 0.86 & 0.83 \\
\hline $\mathrm{C} / \mathrm{N}) \mathrm{a}$ & 13.6 & 15.3 & 13.7 & 10.5 & 10.3 & 13.4 & 13.5 & 13.7 & 10.8 & 11.5 \\
\hline $\mathbf{H}$ & 3.47 & 0.61 & 1.31 & 3.04 & 1.69 & 1.83 & 1.04 & 1.63 & 1.57 & 0.88 \\
\hline $\mathrm{V}$ & 0.17 & 0.09 & 0.10 & 0.16 & 0.24 & 0.03 & - & 0.08 & & 0.08 \\
\hline$S$ & - & - & - & - & - & - & - & - & - & - \\
\hline $\mathrm{C}$ & - & - & - & - & - & - & - & - & - & - \\
\hline$\Sigma 11$ & 72 & 17 & 22 & 124 & 71 & 28 & 17 & 138 & 125 & 79 \\
\hline$\lambda 8$ & 0.17 & 0.09 & 0.10 & 0.16 & 0.24 & 0.03 & - & 0.08 & - & 0.08 \\
\hline $\mathrm{H} / \mathrm{V}$ & 20.41 & 6.78 & 13.10 & 19.00 & 7.04 & 61.00 & - & 20.38 & - & 11.00 \\
\hline $\mathrm{S} / \mathrm{V}$ & 0.00 & 0.00 & 0.00 & 0.00 & 0.00 & 0.00 & - & 0.00 & - & 0.00 \\
\hline $\mathrm{C} / \mathrm{V}$ & 0.00 & 0.00 & 0.00 & 0.00 & 0.00 & 0.00 & - & 0.00 & - & 0.00 \\
\hline \multicolumn{11}{|l|}{ March 95} \\
\hline Depth (m) & 1.5 & 1.5 & 2.2 & 2.8 & 3.8 & 10.1 & 25.5 & 86.1 & 68.6 & 52.5 \\
\hline $\operatorname{POC}(\%)$ & 2.40 & 2.52 & 4.10 & 3.67 & 4.07 & 2.42 & 2.42 & 4.35 & 3.83 & 5.13 \\
\hline PON (\%) & 0.32 & 0.28 & 0.43 & 0.46 & 0.45 & 0.30 & 0.29 & 0.43 & 0.44 & 0.64 \\
\hline $\mathrm{C} / \mathrm{N}) \mathrm{a}$ & 8.8 & 10.5 & 11.1 & 9.3 & 10.6 & 9.4 & 9.8 & 11.8 & 10.2 & 9.4 \\
\hline $\mathrm{H}$ & 0.30 & 1.39 & 0.75 & 0.34 & 1.14 & 1.50 & 1.36 & 1.19 & 1.45 & 1.23 \\
\hline $\mathrm{V}$ & - & - & 0.07 & 0.20 & 0.05 & 0.73 & 0.09 & 0.20 & 0.31 & 0.26 \\
\hline$S$ & 1.32 & 2.67 & 2.35 & 1.32 & 0.21 & 2.99 & 2.14 & 1.31 & 1.50 & 1.97 \\
\hline $\mathrm{C}$ & - & - & - & - & - & - & - & - & - & - \\
\hline$\Sigma 11$ & 39 & 102 & 130 & 68 & 57 & 126 & 87 & 117 & 125 & 177 \\
\hline$\lambda 8$ & 1.32 & 2.67 & 2.42 & 1.52 & 0.26 & 3.72 & 2.23 & 1.51 & 1.81 & 2.23 \\
\hline $\mathrm{H} / \mathrm{V}$ & - & - & 10.71 & 1.70 & 22.80 & 2.05 & 15.11 & 5.95 & 4.68 & 4.73 \\
\hline $\mathrm{S} / \mathrm{V}$ & - & - & 33.57 & 6.60 & 4.20 & 4.10 & 23.78 & 6.55 & 4.84 & 7.58 \\
\hline $\mathrm{C} / \mathrm{V}$ & - & - & 0.00 & 0.00 & 0.00 & 0.00 & 0.00 & 0.00 & 0.00 & 0.00 \\
\hline \multicolumn{11}{|l|}{ July 95} \\
\hline Depth (m) & 1.5 & 1.5 & 1.5 & 1.5 & 1.5 & 15 & 28 & 88 & 71 & 54 \\
\hline $\operatorname{POC}(\%)$ & 5.44 & 5.98 & 9.65 & 9.79 & 8.52 & 4.30 & 5.26 & 9.49 & 8.61 & 6.67 \\
\hline PON (\%) & 0.42 & 0.41 & 0.77 & 1.30 & 0.56 & 0.33 & 0.61 & 0.56 & 1.08 & 0.77 \\
\hline $\mathrm{C} / \mathrm{N}) \mathrm{a}$ & 15.1 & 17 & 14.6 & 8.8 & 17.7 & 15.2 & 10.1 & 19.8 & 9.3 & 10.1 \\
\hline $\mathrm{H}$ & 1.10 & 1.84 & 1.76 & 0.95 & 1.14 & 0.47 & 1.17 & 1.35 & 1.70 & 1.49 \\
\hline $\mathrm{V}$ & 0.16 & 0.05 & 0.23 & 0.14 & 0.16 & 0.19 & - & 0.21 & 0.24 & 0.21 \\
\hline$S$ & 0.58 & 1.92 & 1.56 & 1.49 & 1.61 & 1.38 & 1.85 & 1.63 & 1.82 & 1.61 \\
\hline $\mathrm{C}$ & 0.80 & - & - & - & - & - & - & - & - & - \\
\hline$\Sigma 11$ & 144 & 228 & 343 & 253 & 248 & 88 & 159 & 303 & 324 & 221 \\
\hline$\lambda 8$ & 1.54 & 1.97 & 1.79 & 1.63 & 1.77 & 1.57 & 1.85 & 1.84 & 2.06 & 1.82 \\
\hline $\mathrm{H} / \mathrm{V}$ & 6.88 & 36.80 & 7.65 & 6.79 & 7.13 & 2.47 & - & 6.43 & 7.08 & 7.10 \\
\hline $\mathrm{S} / \mathrm{V}$ & 3.63 & 38.40 & 6.78 & 10.64 & 10.06 & 7.26 & - & 7.76 & 7.58 & 7.67 \\
\hline $\mathrm{C} / \mathrm{V}$ & 5.00 & 0.00 & 0.00 & 0.00 & 0.00 & 0.00 & - & 0.00 & 0.00 & 0.00 \\
\hline
\end{tabular}

from 0.4 to $1.3 \%$ and 0.3 to $1.1 \%$ respectively on the surface and at the bottom in July (figure 3 ). With the exception of the bottom at stations FX9, 10 and 11 in November when relatively high POC and PON contents are observed, seasonal variations consist of an incrcasc in concentrations from November/March to July.
The $\mathrm{C} / \mathrm{N}$ atomic ratio varies between 10 and 15 in November, the lower values being observed in French coastal waters. In March 1995, the C/N ratio is lower and varies little (from 9 to 12) along the transect. In July, this same ratio is more variable than in the other transects and ranges from 8.8 to 20 (table III). 


\subsection{Major classes of organic compounds}

Pyrolysis analyses were only carried out on the deep samples at stations FX7, FX9 and FXI1 (figure 4; table I).

The spatio-temporal distribution of the pyrolysis fragments reveals that deep central waters (FX9) are always characterized by organic material which is enriched in aromatic hydrocarbons and deficient in sugars and to a lesser extent, in nitrogenous compounds (figure 4).

In November, the organic material in French waters is a little more enriched in aromatic hydrocarbons, whereas in English waters, it is quite strongly enriched in sugars, which can be considered as an index of fresher material (figure 4). The concentrations of nitrogenous compounds increase however from English waters towards French waters. This distribution does not mean that the organic matter at FX9 and FX11 has a fresher character.

In March, English waters are definitely richer in nitrogenous compounds, whereas French waters are enriched in aromatic hydrocarbons (figure 4).

In July, the same distribution as in March with regard to aromatic hydrocarbons and nitrogenous compounds is observed. This means that the organic matter is also fresher in English waters.

Characteristic ratio values (table I) provide complementary information particularly on the state of degradation of organic matter. In November 1994 and March 1995, the (furfural + acetic acid) / pyrrol ratio is higher than in July 1995 in the English waters (FX7b), indicating a fresher state of organic matter. On the contrary, benzene / toluene ratios are lower at this station with a high level of acetonitrile / pyrrol ratio.

\subsection{Phenolic compounds: total quantitative analyses}

Yields of total phenols (the sum of vanillyl, syringyl, cinnamyl and hydroxybenzyl phenols) normalised to suspended particulate matter (expressed as the parameter $\Sigma 11)$ are variable in time and space (table III). In autumn (November 1994), concentrations of phenols are weak; on average $69 \pm 48 \mu \mathrm{g} \mathrm{g}^{-1}$ SPM. In spring (March 1995), the average concentration increases to $103 \pm 41 \mu \mathrm{g} \mathrm{g}^{-1}$ SPM, and in summer (July 1995), the phenols content is even higher at $231 \pm 82 \mu \mathrm{g} \mathrm{g}^{-1}$ SPM. Spatial distribution of the parameter $\Sigma 11$ differs from one transect to another.

In November 1994, except for FX9s, the suspensions in French and central waters, are enriched in phenols compared to the particulate material in the English waters (table III). In March 1995, distribution along the transect is extremely variable. On the surface, phenol concentrations increase from the coast towards the centre of the transect, while at the bottom an increase in concentrations is observed from English waters towards French waters (table III). In July 1995, the spatial distribution is rather singular. An increasing gradient from the coast towards the centre of the transect is observed.

\section{DISCUSSION}

\subsection{Variations in SPM along the transect}

The gradient of SPM concentration observed along the transect is related to several factors: on the English side, in addition to the contribution of continental inputs from the Solent, there is noticeable resuspension of the sediments around the Isle of Wight. On the French side, water depth is relatively greater and the waters are not subject to direct telluric influence. As for central waters (FX9), they result from the slightly turbid Atlantic water vein supplying the eastern English Channel. This spatial heterogenity is in agreement with water mass structuration deducted from numerical modelling [34] and physicochemical characteristic of waters along the transect [23]. Dauby et al. [8] observed an increasing gradient in SPM and lithogenic compounds, from the southwest (Celtic Sea) towards the northeast (North Sea), and related it to fluvial inputs and lower water depth.

The seasonal variations in SPM concentrations accentuate two different zones: English coastal waters on the one hand and central and French waters on the other. Regarding the latter, the variations are not very pronounced. In English waters, on the contrary, peaks of SPM are observed in periods of rough weather during which strong winds lead to turbulence and consequently to resuspension, as was the case in November (wind speed: $4.8 \mathrm{~m} \mathrm{~s}^{-1}$ ). The March 1995 transect is characterized by higher SPM contents than the other transects. This sampling cruise coincides with a period which was marked by a notable arrival of continental inputs coming from the Solent and the Seine [25] and an increase in biological activity as shown by the chlorophyll concentrations (2.4-3.8 $\left.\mu \mathrm{g} \mathrm{L}^{-1}\right)[3]$.

\subsection{The POC-SPM relationship}

In general, in fluvial and estuarine environments, the organic carbon content decreases when the SPM load 
November
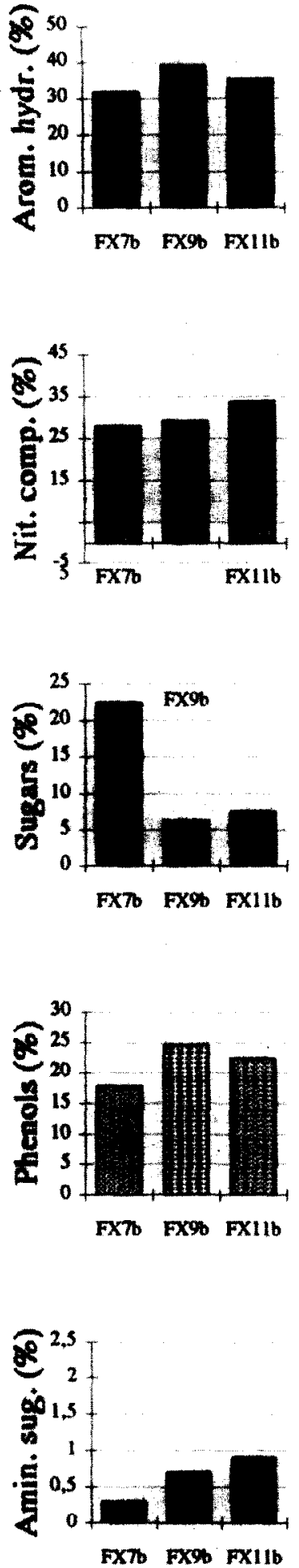

March
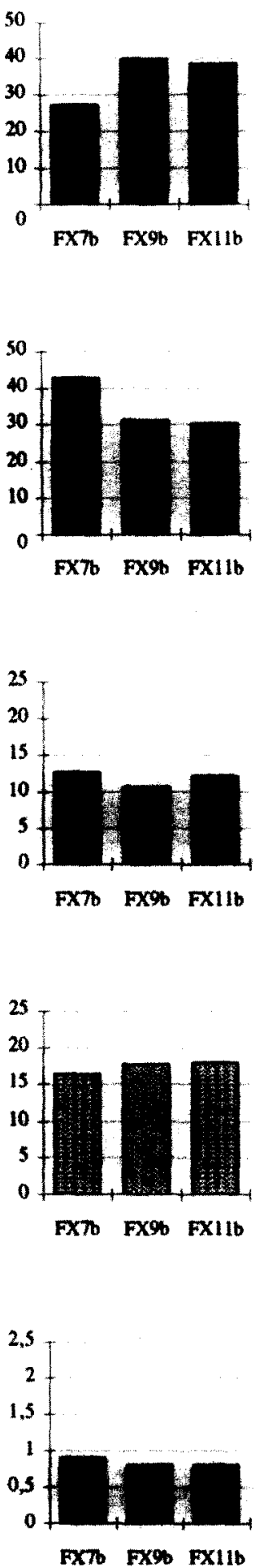

July
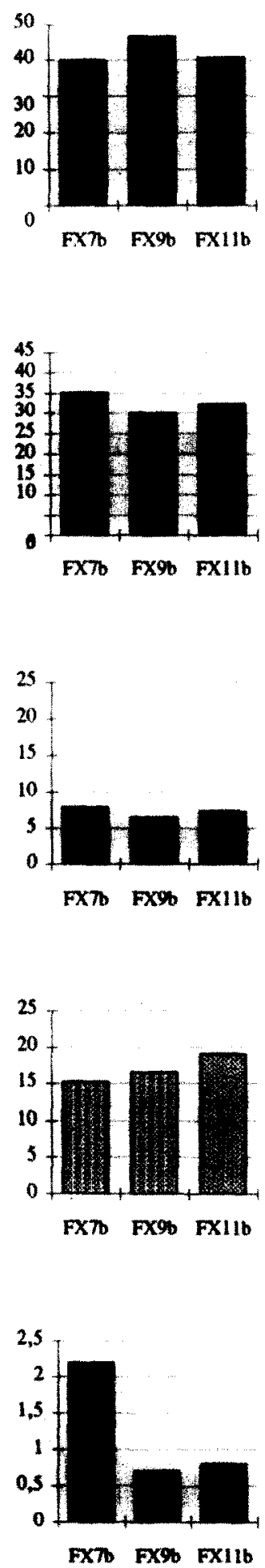

Figure 4. Distribution of the main organic compound classes analysed by Py-GC-MS in bottom samples of the Wight-Cherhourg transect. 

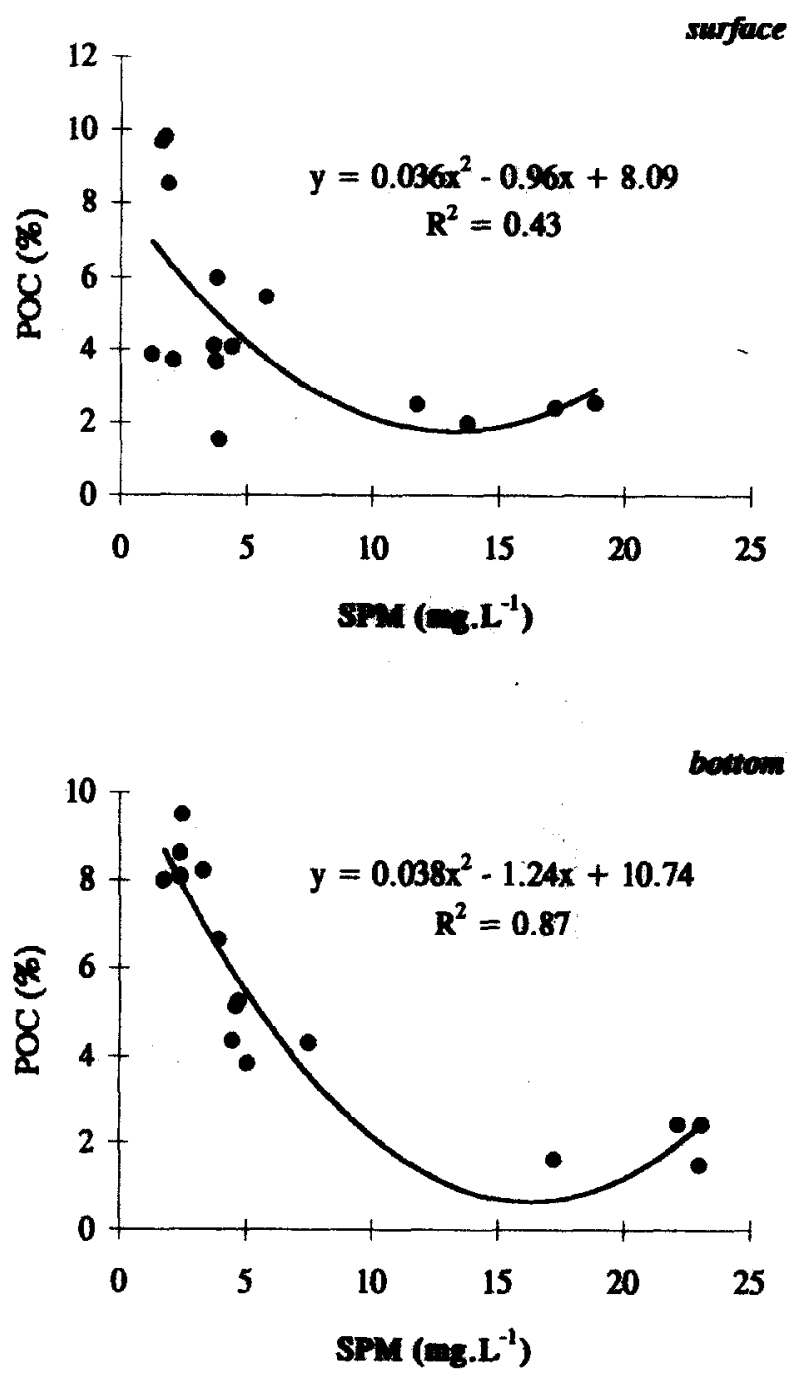

Figure 5. Variation of POC (\%) versus SPM $\left(\mathrm{mg} \mathrm{L}^{-1}\right)$ in surface and bottom waters for November 1994, March and July 1995 transects.

increases, due to dilution by the mineral load [6]. With regard to the transect waters, the relationship between POC (\% SPM) and SPM is hyperbolic (figure 5). This distribution is simultaneously controlled by marine biological production, resuspension processes and contribution of terrestrial inputs. All in all, when SPM content is low $\left(<10 \mathrm{mg} \mathrm{L}^{-1}\right)$, POC $(\%)$ is variable and high, reflecting the variations in biological production. For higher SPM contents (>10 $\mathrm{mg} \mathrm{L}^{-1}$ ), POC (\%) is more or less constant, with low values, demonstrating the influence of resuspension processes on dilution of the organic material.
4.3. Characteristic elemental composition of organic matter

The observed gradient in POC and PON distributions is primarily related to the clear differences in SPM concentrations. As the total lithogenous load is higher in English waters, it contributes to the dilution of organic material in this zone. $\Lambda$ similar gradient based on chlorophyll contents was observed in a France-England transect within the Dover straits [9]. These authors linked this observation to the significant biological productivity along the French coast and/or the predominant mineral contributions in English waters, resulting in the dilution of organic material. The increase in POC and PON contents from November/March to July is related on the one hand to the escalation of biological activity and on the other hand to the weak load in SPM as is the case in July (figures 2, 3).

In November 1994, the nitrogen concentrations, as well as the carbon contents determined at the bottom of central waters (FX9) and French waters (FX10, FX11) attain higher values than those observed on the surface. This is probably related to the heterogeneity of composition of the organic material between the two levels. It seems that during this period of instability, the bottom layers of water at these stations are influenced by contributions related to the resuspension processes. These results confirm those reported by Bodineau et al. [2] who also postulate the possible influence of continental inputs originating from the French coast.

In general, phytoplanktonic material is characterized by a low $\mathrm{C} / \mathrm{N}$ atomic ratio of about 6.6 (106:16, Redfield ratio). According to their $\mathrm{C} / \mathrm{N}$ ratio results, Dauby et al. [8] found values ranging from 5.5 to 7.8 in English Channel waters except for periods of phytoplanktonic development, and conclude that the organic matter is primarily autochthonous. The fact that the C/N of the SPM in the transect is relatively high, whatever the period of study, indicates that the organic material has a composite origin and is more or less degraded. In November, the observed values are influenced by detrital material, since this period is marked by stormy events. In March, it seems that the phytoplanktonic contribution is more sensitive, which is translated into relatively low $\mathrm{C} / \mathrm{N}$ atomic ratios. In July, the organic material which is less influenced by phytoplankton contribution than in March, appears more degraded. It is difficult to characterize the particulate organic matter during July. By using sterols as biomarkers of the organic material sources, Bodineau et al. [2], 
find that the "uncharacterized" organic fraction represents the main part of the POC in July. This badly defined fraction is probably related to a more degraded state of the organic matter in this period, as confirmed by Py-GC-MS analyses.

\subsection{Biogeochemical significance of Py-GC-MS ana- lysis}

The distribution of the main classes of organic compounds underlines the differences between the three defined parts of the transect: English waters are enriched in sugars and/or nitrogenous compounds; central waters, in which the organic matter presents high levels of aromatic hydrocarbons, are rather similar to French waters, which are characterized by slightly lower concentrations of aromatic hydrocarbons.

The fact that central waters are always enriched in aromatic hydrocarbons seems to correspond to the more degraded character of the organic matter in these waters than in the remainder of the transect, as observed elsewhere $[4,10,36]$.

At the station near the English coast, organic matter appears as fresh material, especially since sugars and nitrogenous compounds are more abundant, in November and March respectively. The (furfural+acetic acid) / pyrrol ratio is higher in FX7 (table I), confirming the fresher state [42] of the organic matter in English waters. This observation seems to be related to a double contribution of fresh material: terrestrial inputs and phytoplanktonic activity.

The fresher state of organic matter in the English waters is also observed in July, as in March, in terms of aromatic hydrocarbons and nitrogenous compound contents. The low concentrations of phenols and the abundance of amino sugars in FX7 testify to the marine nature [11] of organic material in those waters. High percentages of acetonitrile and indol $[5,11]$ indicate a stressing marine character and a lower level of degradation of organic matter in English waters compared to French waters (table I).

Nitrogenous compounds increase towards French waters in November. This distribution reflects a more marine origin and a higher state of degradation of organic matter along the French coast, as is confirmed by the concentrations of individual compounds such as acetonitrile, pyrrol and indol [5]. This needs to be put into the context of the assumption of influence by resuspension processes at the bottom of stations FX9, FX10 and FX11. The values of some characteristic ratios, such as lower (furfural+acetic acid) / pyrrol ratios [42] and higher benzene / toluene ratios [40], are indicative of a higher degradation of suspended material in French waters as compared to English waters (table I).

\subsection{Phenols and lignin-derived phenols (HPLC): qualitative analyses}

In November, the distribution of the bulk of the phenols corresponds to the distribution of the organic matter. However, the correlation binding the phenol content $\left(\mu \mathrm{g} \mathrm{g}^{-1} \mathrm{SPM}\right)$ to the POC in (\% SPM), $\left(\mathrm{r}^{2}=0.6 ; \rho=\right.$ $0.85 \%$ ) is not significant enough (figure 6). This suggests a certain heterogeneity of the organic phase along the transect which may be related to the diversity of sources (terrestrial, i.e. eolian and fluvial, autochthonous) or to the influence of resuspension processes.

During March, the correlation between phenols and POC $\left(r^{2}=0.26 ; p=12 \%\right)$, is not significant (figure 6). This seems to indicate that this period is characterized by the coexistence of continental inputs and phytoplanktonic activity.

In contrast to the other transect, in July, the correlation binding phenols to the POC is significant $\left(r^{2}=0.80 ; \rho=\right.$ $0.05 \%$ ) (figure 6 ). This correlation means that organic matter inputs are uniformly enriched in phenolic compounds throughout the entire system (table III). It may be thought that these more stable compounds are less degraded than the other organic molecules (sugars, amino acids). This is consistent with the fact that the organic matter which has been degraded during this period is enriched in pyrolysis-derived aromatic hydrocarbons. Neverthless, the spatio-temporal distribution of phenolic compounds analysed by HPLC does not demonstrate the same trend with pyrolysis-derived phenols. One probable explanation is that the pyrolysis-derived phenols are byproducts possibly originating from aromatic amino acids and carbohydrates $[10,42]$.

\subsection{Estimates of the terrestrial contribution to POC}

In interpreting the phenolic composition for the suspended material of each transect, we dissociated the vanillyl (V), syringyl (S) and cinnamyl (C), which are of strictly continental origin, from the hydroxybenzyl $(\mathrm{H})$, whose source is much debated [15,20]. A total content of $\lambda 8$ (mg g $\left.\mathrm{m}^{-1} \mathrm{POC}\right)$ corresponding to the sum $(\mathrm{V}+\mathrm{S}+\mathrm{C})$ normalised to the organic matter provides information about the significance of terrestrial contribution to the organic material in the samples. 

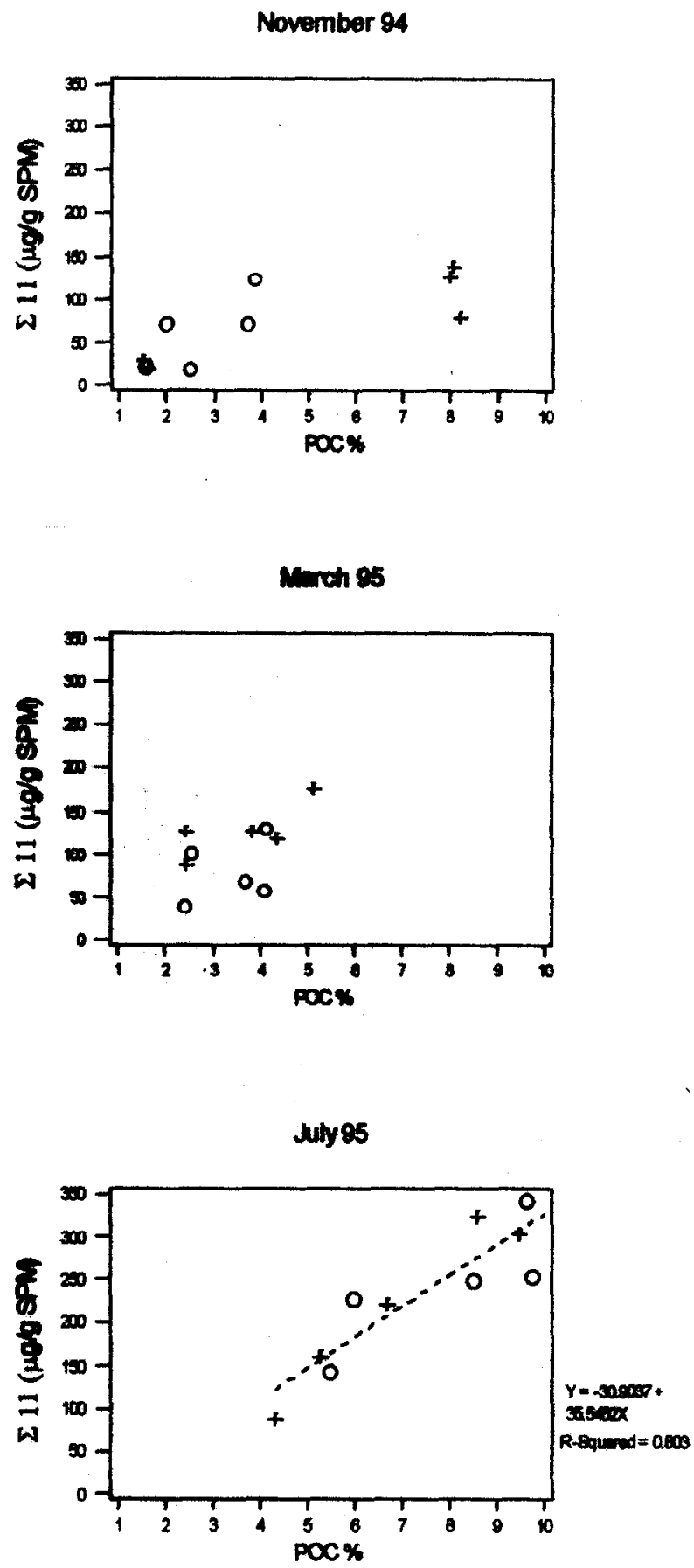

Figure 6. Relationships between concentrations of phenolic compounds ( $\mu \mathrm{g} \mathrm{g}^{-1}$ SPM) and POC $(\%)$ for November 1994, March and July 1995 transects (O : surface; + : bottom).

The distribution of $\lambda 8$ data allows the transect to be divided into three sectors: English waters (FX7/FX8), central waters (FX9) and French waters (FX10/FX11).
The average calculated concentrations for each sector appear in table $I V$. These data bring to light evidence that the incidence of terrestrial inputs is higher in March than in July and very low in November, especially as the determined terrestrial markers are near their detection limit. This needs to be considered alongside the probable flood period of the continental discharges (the Solent, the Seine etc.). English waters seem to be the most influenced by the organic matter of continental origin, and the influence of the terrestrial contribution on central water is very sensitive when the waters are rising. A slightly higher contribution can be observed in French coastal waters in July compared to March 1995. This characteristic could indicate the influence of circulation of coastal waters around the Cotentin Peninsula from the Golfe Normand-Breton and the Baie de Seine. The same conclusion was reported with regard to the distribution of the fluorescent dissolved organic matter [24].

Table IV. Mean lignin-derived phenol $\lambda .8=(\mathrm{V}+\mathrm{S}+\mathrm{C})$ contents normalised with respect to $\mathrm{POC}$ and distribution trends by sectors in November 1994, March and July 1995.

\begin{tabular}{lccc} 
& \multicolumn{3}{c}{$\lambda \mathbf{8}$ (mg/g POC) } \\
\cline { 2 - 4 } & $\begin{array}{l}\text { English } \\
\text { waters }\end{array}$ & $\begin{array}{l}\text { Central } \\
\text { waters }\end{array}$ & $\begin{array}{l}\text { French } \\
\text { waters }\end{array}$ \\
\hline November 94 & $\begin{array}{c}\text { FX7/FX8 } \\
\text { March 95 }\end{array}$ & FX9 & FX10/FX11 \\
July 95 & $2.49 \pm 0.075$ & $0.09 \pm 0.01$ & $0.12 \pm 0.10$ \\
& $1.73 \pm 0.21$ & $1.97 \pm 0.64$ & $1.46 \pm 0.85$ \\
\end{tabular}

In November, the content of lignin-derived phenols is lower (table III). The detection of only vanillyl phenols in small quantities is related to the minor presence of highly transformed terrestrial material, originating from gymnosperm and angiosperm tissues. In March, the phenolic composition is characterized by a predominance of syringyl phenols. The latter are specific compounds of lignin resulting from angiosperms [13]. Their presence indicates a continental input of organic material with a relatively low level of degradation $[11,21]$ which has been transported out to sea during the flood period (February, March 1995). At the site of the July transect, the inputs of woody phenols to the organic matter are distributed in a more or less homogeneous way. Their values range between 1.5 and $2 \mathrm{mg} \mathrm{g}^{-1} \mathrm{POC}$. This distribution implies a uniformity in the contribution of terrestrial material to the total organic matter. This is probably related to the deceleration of hydrological circulation 


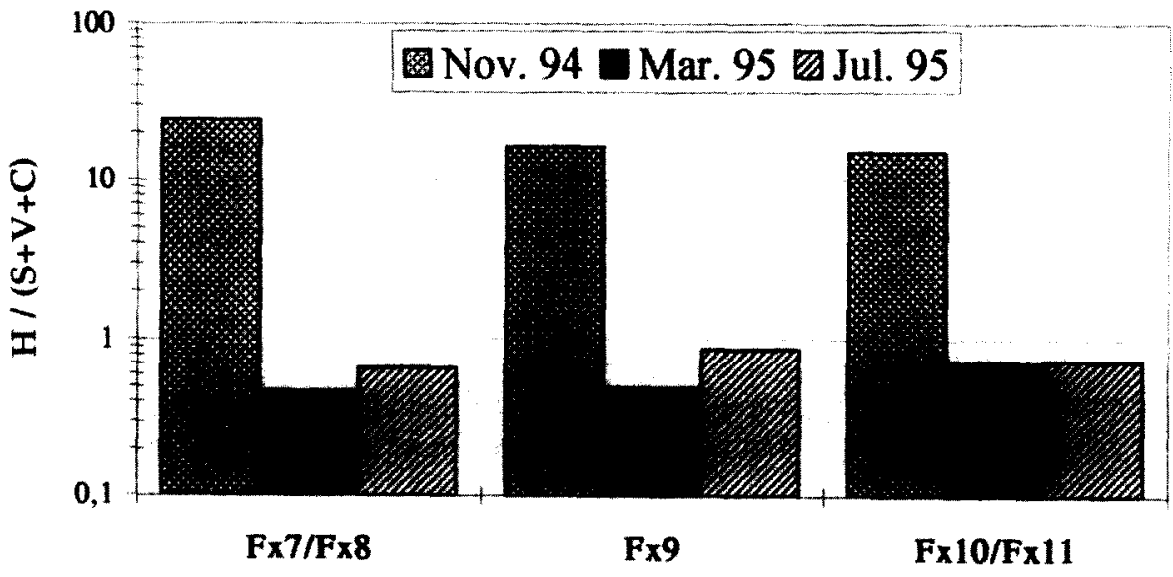

Figure 7. Diagram of $\mathrm{H} /(\mathrm{V}+\mathrm{S}+\mathrm{C})$ ratio for the three sectors of the transect during November 1994, March and July 1995. across the transect during this period, but also to the more highly transformed character of the organic matter (enrichment in aromatic hydrocarbons) than in the other transects.

\subsection{Estimates of the indigenous contribution to POC}

Hydroxybenzyl phenols are provided by alkaline oxidation of lignin $[16,18,35]$ but can also be produced by nonvascular organisms belonging to phytoplankton, marine algae and bacteria $[12,16]$. If the hydroxybenzyl phenols do not have the same proportions as they have in lignin, then a phytoplanktonic and algal origin can be put forward for them [20]. In all the samples from the transect, the hydroxybenzyl phenols are present in notable quantities and the $\mathrm{H} / \mathrm{V}$ ratio varies between 1.7 and 61 (table III). In the natural samples, this ratio is generally low at $<2[20,22]$. Moreover, the $\mathrm{p}$-hydroxyacetophenone which is typically produced by the lignin cupric oxide alkaline oxidation is noticeably absent from all the samples whatever the period. This indicates that the two other $\mathrm{H}$ phenols (p-hydroxybenzaldehyde and p-hydroxybenzoic acid) probably result from marine organisms (algae, phytoplankton and bacteria). Therefore, in the waters of the transect, hydroxybenzyl would seem to constitute marine tracers. These results concur with those of Van Heemst et al. [41] who report that polyphenols of algal origin constitute a significant source of marine POC and DOC. Furthermore, the phenolic compounds analysed by $\mathrm{H}$. Texier [unpubl. data] in the phytoplankton collected along the littoral of Pas-de-Calais, and by Hedges and Parker [19] on two nonvascular plants (brown and blue-green alga), display nearly exclusive concentrations of $\mathrm{p}-\mathrm{OH}$ benzaldehyde and $\mathrm{p}-\mathrm{OH}$ benzoic acid.

According to the $\mathrm{H}$ concentrations (table $\mathrm{V}$; figure 7), the marine contribution to the phenolic part of organic matter reaches its maximum in November 1994 when the terrestrial component is very limited. In March 1995, H concentrations are weaker than the lignin-derived phenols $(\mathrm{V}, \mathrm{S}, \mathrm{C})$. They arc dominated by the substantial terrigenous flow. In July, macroalgae bloom and degradation may contribute to the increase in $\mathrm{H}$ phenols.

Table V. Mean hydroxybenzyl phenol contents $(\mathrm{H})$ normalised with respect to POC contents and distribution trends by sectors in November 1994, March and July 1995.

\begin{tabular}{lccc}
\hline & \multicolumn{3}{c}{ Hydroxybenzyl (mg/g POC) } \\
\cline { 2 - 4 } & $\begin{array}{c}\text { English } \\
\text { waters }\end{array}$ & $\begin{array}{c}\text { Central } \\
\text { waters }\end{array}$ & $\begin{array}{c}\text { French } \\
\text { waters }\end{array}$ \\
\hline & FX7/FX8 & FX9 & FX10/FX11 \\
November 94 & $1.74 \pm 1.26$ & $1.47 \pm 0.22$ & $1.80 \pm 0.90$ \\
March 95 & $1.14 \pm 0.56$ & $0.97 \pm 0.31$ & $1.04 \pm 0.48$ \\
July 95 & $1.15 \pm 0.56$ & $1.56 \pm 0.29$ & $1.32 \pm 0.34$ \\
\hline
\end{tabular}

\section{CONCLUSIONS}

The central English Channel functions as a hydrodynamic system with three zones: central waters bordered by English coastal waters on one side and French waters on the other. In this system, an increasing gradient in suspended particulate material is established from the south towards the north. This distribution is the consequence of 
the reduction of the water column, i.e. resuspension processes, combined with telluric inputs to English coastal waters. A reversed north-south gradient is observed in the SPM organic content. This outline fits well with the distribution of the suspended matter itself. As SPM is more abundant in English waters, it contributes to the dilution of organic matter. The spatio-temporal distribution of the major classes of organic compounds analysed by Py-GC-MS reveals that organic matter in central waters is degraded, duc to its long transit in the Atlantic water vein. This is consistent with enrichment in phenolic compounds (HPLC). Along the transect, the organic matter appears least degraded in March and most degraded in July. This is related to the influence of terrestrial contributions and the increase in phytoplanktonic activity in March. As for July, it is a "post-bloom" period when heterotrophic activity (zooplankton, bacteria) contributes further to the state of decomposition of organic matter. The organic material appears more degraded in French waters than in English waters. This character of organic matter in French waters is probably related to the fact that they are closer to central waters, where the organic material undergoes the most transformations. HPLC analysis of the phenolic compounds produces new information about the nature and origin of the organic matter. Indeed, the terrestrial contribution is underlined by the increase in total phenols in SPM and organic matter, particularly in phenols of the vanillyl and syringyl groups. These two families of lignin-derived phenols constitute terrigenous markers of inputs introduced by river flows into the marine environment. The presence of other compounds. such as hydroxybenzyl, emphasises the obvious marine origin of the organic material. This is particularly clear in November when the indigenous contribution correlates with a reduced incidence in terrestrial contribution. The qualitative analysis of phenols also allowed the seasonal variations in terrestrial inputs to be detected and a taxonomic origin for a part of the particulate matter to be proposed. Thus, in March and July 1995, it can indeed be observed that terrestrial contributions are enriched in angiosperm remains, while in November 1994, the terrestrial material seems to show a more pronounced pedological origin, being essentially composed of vanillyl phenols derived from lignin and humified organic matter.

\section{Acknowledgements}

This work was carried out within the framework of the European Programme MAST II (FluxManche II, contract MAS 2 - CT 94 - 0089). The authors thank L. Cabioch and $\mathrm{M}$. Wartel, the co-ordinators of the programme. They also thank P.J. Statham who was in charge of the topic "Fluxes and Biogeochemical Processes", and their Spanish colleagues D. Lopez and L. Comellas (Institut Químic de Sarrià, Barcelona) for their invaluable assistance in Pyrolysis analyses. Thanks are also due to the crews of the oceanographic ships: Noroit, Thalia II and Côte d'Aquitaine, and to the technicians J.-L. Blazi and J. Quillard.

\section{REFERENCES}

[1] Belin C., Texier H., Lamotte M., Ewald M., Fluorometric characterization of the Seine estuary, Seine bay and French coastal Channel waters, Estuar. Coast. Shelf Sci. (in press).

[2] Bodineau L., Thoumelin G., Wartel M., Task G., Seasonal fluxes and changes in composition of organic matter in the eastem Channel, Final report FluxManche II (1996) 192-204.

[3] Boxall S., Bishop C., Nash L., Santer R., Chami M., Dilligeard E., Wernand M., Matthews A., Task W. Physical processes and field measurements, Final report FluxManche II (1996) 53-72.

[4] Bracewell J.M., Robertson G.W., A pyrolysis-gas chromatography method for discrimination of soil humus types, J. Soil Sci. 27 (1976) 196-205.

[5] Bruchet A., Rousseau C., Mallevialle J., Pyrolysis-GC-MS for investigating high-molecular weight THM Precursors and other refractory organics, J. AWWA Res. Technol. (1990) 6674.
[6] Cauwet G., Sidorov I., The biogeochemistry of Lena River: organic carbon and nutrients distribution, Mar. Chem. 53 (1996) 211-227.

[7] Charrière B., Les composés phénoliques marqueurs de la matière organique terrestre dans deux écosystèmes marins : le delta du Rhône et le prodelta de la Têt, thèse Instit. Nat. Polytechn. Toulouse (1991) $182 \mathrm{p}$.

[8] Dauby P., Frankignoulle M., Gobert S., Bouquegneau J.-M., Distribution of $\mathrm{POC}, \mathrm{PON}$ and particulate $\mathrm{Al}, \mathrm{Cd}, \mathrm{Cr}, \mathrm{Cu}, \mathrm{Pb}$, $\mathrm{Ti}, \mathrm{Zn}$ and $\mathrm{d} 13 \mathrm{C}$ in the English Channel and adjacent areas, Oceanol. Acta 17 (6) (1994) 643-657.

[9] Dupont J.-P., Collins M.B., Lafite R., Nash L., Huault M.F., Shimwell S.J., Chaddock S., Brunet C., Wartel M., Lamboy. M., Annual variations in suspended particulate matter within the Dover Strait, Oceanol. Acta 16, 5-6 (1993) 507-516. 
[10] Gadel F., Charrière B., Serve L., Chemical characterization of suspended particulate organic matter by pyrolysis-gas chromatography coupled with mass spectrometry and high performance liquid chromatography in the bottom nepheloid layer of the Rhône Delta, Estuar. Coast. Shelf Sci. 37 (1993) 221-236.

[11] Gadel F., Puigho A., Alcaniz J.M., Charrière B., Serve L., Tracers and constituents indicating the nature of organic fluxes, their origin and the effect of environmental conditions, Continent. Shelf Res. 10 (1990) 1039-1062.

[12] Goñi M.A., Hedges J.I., Sources and reactivities of marinederived organic matter in coastal sediments as determined by alkaline CuO oxidation, Geochim. Cosmochim. Acta 59 (1995) 2965-2981.

[13] Goñi M.A., Hedges J.I., Lignin dimers: Structures, distributions, and potential geochemical applications, Geochim. Cosmochim. Acta 56 (1992) 4025-4043.

[14] Goñi M.A., Ruttenberg K.C., Eglinton T.I., Sources and contribution of terrigenous organic carbon to surface sediments in the Gulf of Mexico, Nature 389 (1997) 275-278.

[15] Gough M.A., Mantoura R.F.C., Preston M., Terrestrial plant biopolymers in marine sediments, Geochim. Cosmochim. Acta 57 (1993) 945-964.

[16] Haddad R.I., Martens C.S., Biogeochemical cycling in an organic-rich coastal marine basin: Sources and accumulation rates of vascular plant-derived organic matter, Geochim. Cosmochim. Acta 51 (1987) 2991-3001.

[17] Hedges J.I., Ertel J.R., Characterization of lignin by gas capillary chromatography of cupric oxide oxidation products, Anal. Chem. 54 (1982) 174-178.

[18] Hedges J.I., Mann D.C., The characterization of plant tissues by their lignin oxidation products, Geochim. Cosmochim. Acta 43 (1979) 1803-1807.

[19] Hedges J.I., Parker P.L., Land-derived organic matter in surface sediments from the Gulf of Mexico, Geochim. Cosmochim. Acta 40 (1976) 1019-1029.

[20] Hedges J.I., Clark W.A., Cowie G.L., Organic matter sources to the water column and surficial sediments of a marine bay, Limnol. Oceanogr. 33 (1988a) 1116 -1136.

[21] Hedges J.I., Clark W.A., Cowie G.L., Fluxes and reactivities of organic matter in a coastal marine bay, Limnol. Oceanogr. 33 (1988b) 1137-1152.

[22] Hedges J.I., Clark W.A., Quay P.D., Richey E.J., Devol A.H., Santos U.M., Compositions and fluxes of particulate organic material in the Amazon River, Limnol. Oceanogr. 31 (1986) 717-738.

[23] Ismaïli M.M., Traceurs dissous et particulaires de la matière organique dans l'estuaire de la Seine, la baie de Seine et la Manche centrale, thèse doct. univ. Caen (1998) $180 \mathrm{p}$.

[24] Ismaili M.M., Belin C., Lamotte M., Texier H., Distribution et caractérisation par fluorescence de la matière organique dissoute dans les eaux de la Manche centrale, Oceanol. Acta 21 (5) (1998) 645-654.

[25] Lafite R., Dupont J.P., Huault M.F., Dethleff D., Velegrakis A.F., Bishop C., Collins M.B., Task S: Large-scale sedimento- logical/hydrodynamical field measurements, Final report FluxManche II (1998) 144-150.

[26] Louchouarn P., Lucotte M., Canuel R., Gagné J.P., Richard L.P., Sources and early diagenesis of lignin and bulk organic matter in the sediments of the Lower Saint Lawrence Estuary and the Saguenay Fjord, Mar. Chem. 58 (1997) 3-26.

[27] Meyers-Schulte K.J., Hedges J.I., Molecular evidence for a terrestrial component of organic matter dissolved in ocean water, Nature 321 (1986) 61-63.

[28] Opsahl S., Benner R., Distribution and cycling of terrigenous dissolved organic matter in the ocean, Nature 386 (1997) 480482.

[29] Pocklington R., Mc Gregor C.D., The determination of lignin in marine sediments and particulate form seawater, Int. J. Environ. Anal. Chem. 3 (1973) 81-93.

[30] Poulicek M., Jeuniaux C., Distribution et flux de composés organiques particulaires et dissous en Manche et en mer du Nord. Apports, biomasses et biodégradation des composés organiques naturels, Bul. Soc. R. Sci. Liège 63 (1994) 89-165.

[31] Prahl F.G., Ertel J.R., Goñi M.A., Sparrow M.A., Eversmeyer B., Terrestrial organic carbon contributions to sediments on the Washington margin, Geochim. Cosmochim. Acta 58 (1994) 3035-3048.

[32] Reeves A.D., Preston M.R., The composition of lignin in estuarine suspended particulates and the distribution of particulate lignin in estuaries as determined by capillary gas chromatography of cupric oxide oxidation products, Estuar. Coast. Shelf Sci. 29 (1989) 583-599.

[33] Ruttenberg K.C., Goñi M.A., Phosphorus distribution, C:N:P ratios, and $\delta 13 \mathrm{C}_{\mathrm{oc}}$ in arctic, temperate, and tropical coastal sediments: tools for characterizing bulk sedimentary organic matter, Mar. Geol. 139 (1997) 123-145.

[34] Salomon J.-C., Breton M., Courants résiduels de marée dans la Manche, Oceanol. Acta, vol. sp. 11 (1991) 47-53.

[35] Sarkanen K.V., Ludwig C.H., Definition and nomenclature, in: Sarkanen K.V., Ludwig C.H. (Eds.), Lignins: occurrence, formation, structure and reaction, Wiley Interscience, Part 1, Ch. 3 (1971) 10-16.

[36] Seres-Aspax A., Alcañiz J.M., Gassiot M., Application of pyrolysis-gas chromatography to the study of the composting process of barley straw and pear-tree wood, J. Anal. Appl. Pyrol. 8 (1985) 415-426.

[37] Serve L., Icole M., Blazi J.L., Les monomères phénoliques dérivés des lignines dans les sédiments d'une carotte longue du lac du Bouchet (Massif central, France) et la reconstitution des paléoenvironnements, Bull. Soc. Géol. Fr. 168 (4) (1997) 37-52.

[38] Sicre M.A., Peulvé S., Saliot A., De Leeuw J.W., Baas M., Molecular characterization of the organic fraction of suspended matter in the surface waters and bottom nepheloid layer of the Rhone delta using analytical pyrolysis, Org. Geochem. 21 (1994) 11-26.

[39] Texier H., Lafite R., Dupont J.P., Firmin V., Gadel F., Serve L., Charrière B., Organic matter transport across a macrotidal 
M.M. ISMAïLI et al.

estuary gradient: the Seine estuary, France, Neth. J. Aquat. Ecol. 27 (1993) 405-413.

[40] Trasar-Cepeda M.C., Ceccanti B., Leiros M.C., Calcinai M., Gil-Sotres F., Characterization of organic matter in lignite minesoils at various ages by Pyrolysis-gas chromatography, in: Senesi N., Miano T.M. (Fds.), Humic Substances in the Glohal Environment and Implications in Human Health (1994) $707-$ 712 .
[4I] Van Heemst J.D.H., Peulvé S., De Leeuw J.W., Novel algal polyphenolic biomolecules as significant contributors to resistant fractions of marine dissolved and particulate organic matter, Org. Geochem. 24 (1996) 629-640.

[42] Wilson M.A., Philp R.P., Gilbert T.D., Tate K.R., Comparison of the structures of humic substances from aquatic and terrestrial sources by pyrolysis - gas chromatography - mass spectrometry, Geochim. Cosmochim. Acta 47 (1983) 497-502. 